UDC: 598.265 .1

\title{
SYNANTHROPIZATION OF WOODPIGEON (COLUMBA PALUMBUS) IN UPPER POBUZHIA (UKRAINE)
}

\author{
V. V. Novak \\ Municipal Institution of Higher Education \\ "Bar Humanitarian Pedagogical College named after Mykhailo Hrushevskyi" \\ 1 Hrushevskyi Sq., Bar, Vinnytsia Region 23000, Ukraine \\ Corresponding author e-mail: novakvova@ukr.net
}

Novak V.V. Synanthropization of Woodpigeon (Columba palumbus) in Upper Pobuzhia (Ukraine). Studia Biologica, 2021; 15(2): 73-80 • DOI: https://doi.org/10.30970/sbi.1502.650

Background. Significant (over $20 \%$ ) forest cover of the region, a wide network of woodland belts, a high level of greening of villages and more than 200-year-old gardening traditions create favorable conditions for the existence of the Woodpigeon (Columba palumbus) and its settlement. Despite a rather wide distribution of the species in the region, its biological characteristics and the process of synanthropization remain insufficiently studied.

Materials and Methods. The study was conducted during 2006-2020. Breeding Bird Survey routes without zone limitations and spot surveys were performed to assess the density of the species. Records of the location and height of the nest, its size, the presence of egg-laying or nestlings, the age of the nestlings and building material were made for each nesting site. The main part of the material on rural settlements was collected on the territory of monitoring sites "Chornyi Ostriv" and "Medzhibizh", which covered 6 villages. Unpublished materials on the species in the region, collected by V. O. Novak in the period of 1990-2010, were also processed.

Results and Discussion. The Woodpigeon is a nesting migratory species in Upper Pobuzhia region. In recent decades, the region has seen a process of synanthropization of the species. The first cases of Woodpigeon nesting in the settlements of Upper Pobuzhia (west of Khmelnytskyi city) were discovered by V. I. Gulay in 1986-1990. In the region, woodpigeons first nested in villages (since 1986) and only then in the city of Khmelnytskyi (the first nest was found on 11.05.1994). Of the 390 registered nests, the share of identified nests $(n=390)$ in the settlements of Upper Pobuzhia was $50 \%$ in the period of $1990-2000,64 \%$ in the period of $2001-2010$, and $81 \%$ in the period of 2010 2020. In the parks of Khmelnytskyi, the density of nesting in 2020 was 35 pairs $/ \mathrm{km}^{2}$,

() 2021 V. V. Novak. Published by the Ivan Franko National University of Lviv on behalf of Біологічні Студії / Studia Biologica. This is an Open Access article distributed under the terms of the Creative Commons Attribution License (http://www.budapestopenaccessinitiative.org and Creative Commons Attribution 4.0 License), which permits unrestricted reuse, distribution, and reproduction in any medium, provided the original work is properly cited.

ISSN 1996-4536 (print) • ISSN 2311-0783 (on-line) • Біологічні Студії / Studia Biologica • 2021 • Том 15 / № 2 • С. $73-80$ 
while in the forests of the region -4 pairs $/ \mathrm{km}^{2}$. On some streets of Khmelnytskyi, the density of nesting species is even higher -43 pairs $/ \mathrm{km}^{2}$. In rural settlements, the Woodpigeon average density during the nesting period is 1.7 pairs $/ \mathrm{km}^{2}$, although in some villages it can reach 11 pairs $/ \mathrm{km}^{2}$. The birds use 33 species of trees and bushes and some structural elements of houses as support for the nest. In the process of synanthropization, the Woodpigeon has developed new adaptations in nesting and searching for food.

Conclusion. The process of synanthropization of the Woodpigeon in Upper Pobuzhia region has been taking place for the last 30 years. In its foraging behavior and tolerance to humans, it resembles a typical synanthropus - Feral Pigeon Columba livia, which indicates the successful synanthropization of the species.

\section{Keywords: Woodpigeon, nesting, synanthropization, Upper Pobuzhia}

\section{INTRODUCTION}

The region of Upper Pobuzhia covers the upper part of the basin of the Southern Bug River within the boundaries of Vinnytsia (west of the city of Vinnytsia) and Khmelnytskyi regions (central part of the region). Significant (over $20 \%$ ) forest cover of the region, a wide network of woodland belts, a high level of greening of villages and more than 200-year-old gardening traditions create favorable conditions for the existence of the Woodpigeon (Columba palumbus) and its settlement. Despite a rather wide distribution of the species in the region, its biological characteristics and the process of synanthropization remain insufficiently studied. The purpose of this study was to find out the density of the species during the nesting period, the peculiarities of its nesting and behavior in the settlements of Upper Pobuzhia region resulting from synanthropization.

\section{MATERIALS AND METHODS}

The study was conducted during 2006-2020 in natural biotopes, rural settlements of the region and in Khmelnytskyi, Derazhnia, Bar, Letychiv. Breeding Bird Survey routes without zone limitations and spot surveys were performed to assess the density of the species [6, 19]. Absolute nest counting was performed in some areas. If possible, the location and height of the nest, its size, the presence of egg-laying or nestlings, the age of the nestlings, building material, and in populated areas - the distance from buildings, sidewalks and streets were recorded for each nest. The main part of the material on rural settlements was collected on the territory of monitoring sites "Chornyi Ostriv" and "Medzhibizh", which covered 6 villages, that differed in the number of inhabitants, the degree of urbanization and some other parameters [16]. Routes for bird count were laid out in each settlement so that the count area would cover the settlement as completely as possible. This excluded the possibility of passing the same route during one count. The speed of the check man was 3-4 km/h. Unpublished materials on the species in the region, collected by V. O. Novak in the period of 1990-2010, were also processed.

\section{RESULTS AND DISCUSSION}

The Woodpigeon is a nesting migratory species in Upper Pobuzhia region [15]. For a long time, woodpigeons inhabited only the forests of the region $[4,8,17]$. In recent decades, the region has seen a process of synanthropization of the species, which began in Western Europe in the second half of the nineteenth century, resulting in the formation

ISSN 1996-4536 (print) • ISSN 2311-0783 (on-line) • Біологічні Студії / Studia Biologica • 2021 • Том 15 / № 2 • C. 73-80 
of synanthropic populations of the species in all European countries by the end of the twentieth century $[3,22]$. The first cases of the Woodpigeon nesting in the settlements of Upper Pobuzhia (west of Khmelnytskyi city) were discovered by V. I. Gulay during 1986-1990 [5]. According to our data, an active process of synanthropization of the species has taken place in the region. Nearly in the same period, synanthropization of the Woodpigeon started in the neighboring regions of Western Ukraine [1, 7, 22]. However, in Central and Eastern Ukraine, the process of synanthropization began only at the beginning of the XXI century and is not so intense [9, 14, 20, 24]. Furthermore, while for other regions researchers note the nesting of the Woodpigeon in cities $[1,7,9,12,20$, $22,24]$, in our region, woodpigeons first nested in villages (since 1986) and only then in the city of Khmelnytskyi (the first nest was found on 11.05.1994).

Analysis of the reliable cases of nesting of the species registered by us in different biotopes $(n=390)$ revealed that the share of identified nests in the settlements of Upper Pobuzhia was $50 \%$ in the period of 1990-2000, $64 \%$ in the period of 2001-2010, and $81 \%$ in the period of 2010-2020 (see Figure).

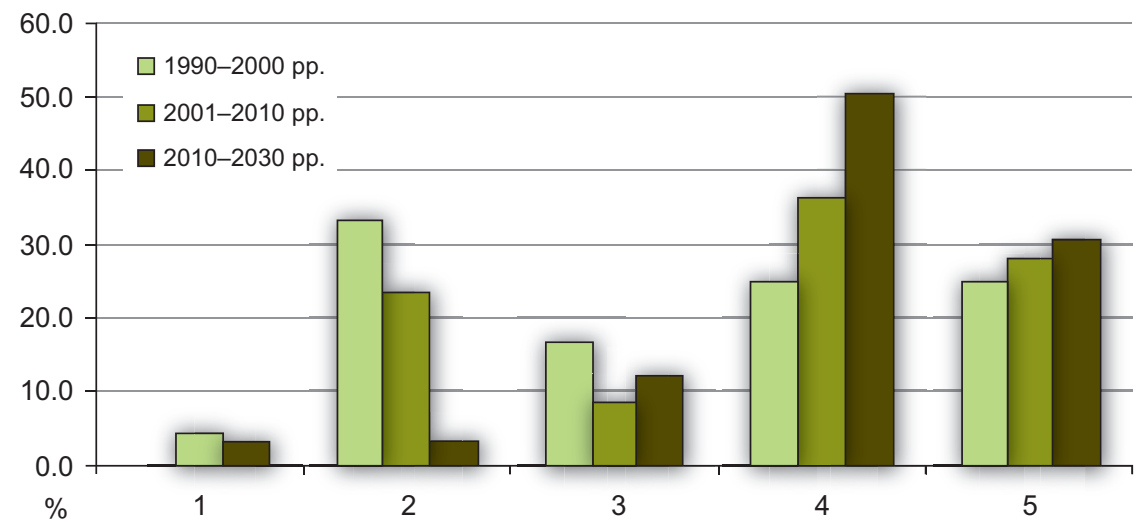

Proportion (\%) of identified Woodpigeon nests in various biotopes of Upper Pobuzhia region in 19902020: 1 - riverside planting zones; 2 - woodland belts; 3 - forests; 4 - villages; 5 - cities.

Частка (\%) виявлених гнізд припутня у різних біотопах Верхнього Побужжя в 1990-2020 роках: 1 - прибережні насадження; 2 - лісосмуги; 3 - ліси; 4 - села; 5 - міста

It should be noted that in $2010,27.7 \%$ of the nests that we found were in in the city of Khmelnitskyi. At that time, in the city of Vinnytsia (the eastern border of our region), the Woodpigeon was found only in the post-nesting period [13], and by 2017 its nests had already been registered in parks and squares of the city [14]. Today, the number of woodpigeons in city parks significantly exceeds their number in forests $[9,20]$. According to our data, in the parks of Khmelnytskyi, the density of nesting in 2020 was 35 pairs $/ \mathrm{km}^{2}$, while in the forests of the region - 4 pairs $/ \mathrm{km}^{2}$. On some streets of Khmelnytskyi (Prospekt Myru, Zarichanska Street), in areas of multi-storey buildings, the density of nesting species is even higher - 43 pairs $/ \mathrm{km}^{2}$. In rural settlements, the Woodpigeon average density during the nesting period is 1.7 pairs $/ \mathrm{km}^{2}$, whereas in some villages it can reach 11 pairs $/ \mathrm{km}^{2}$.

Analysis of the Woodpigeon nests for which the exact location is known ( $n=382)$ showed that birds use 33 species of trees and bushes and some structural elements of houses as support for their nests (see Table). In riverside planting zones, the Woodpigeon nests on 7 species of trees (mainly on Salix alba - 30\% of all cases in a biotope), 
in woodland belts - on 9 (mainly on Prunus cerasifera - $38 \%$ of all cases in a biotope), in forests - on 15 (mainly on Carpinus betulus - $30 \%$ of all cases in a biotope), in cities on 20 (mainly on Acer platanoides - $26 \%$ of all cases in cities), in villages - on 23 (mainly on Tilia cordata $-15 \%$ of all cases in villages).

The number of found Woodpigeon nests located on different species of trees Кількість знайдених гнізд припутня на деревах різних dblsd

\begin{tabular}{|c|c|c|c|}
\hline No & Species & Number & $\%$ \\
\hline 1 & Prunus cerasifera & 35 & 9.2 \\
\hline 2 & Euonymus europaeus & 2 & 0.5 \\
\hline 3 & Ulmus minor & 2 & 0.5 \\
\hline 4 & Sambucus nigra & 3 & 0.8 \\
\hline 5 & Syringa vulgaris & 3 & 0.8 \\
\hline 6 & Betula pendula & 14 & 3.7 \\
\hline 7 & Salix alba & 13 & 3.4 \\
\hline 8 & Salix babylonica & 2 & 0.5 \\
\hline 9 & Salix pentandra & 1 & 0.3 \\
\hline 10 & Prunus cerasus & 9 & 2.4 \\
\hline 11 & Alnus glutinosa & 2 & 0.5 \\
\hline 12 & Aesculus hippocastanum & 17 & 4.5 \\
\hline 13 & Juglans regia & 14 & 3.7 \\
\hline 14 & Carpinus betulus & 16 & 4.2 \\
\hline 15 & Pyrus communis & 14 & 3.7 \\
\hline 16 & Sorbus aucuparia & 5 & 1.3 \\
\hline 17 & Crataegus sp. & 5 & 1.3 \\
\hline 18 & Quercus robur & 5 & 1.3 \\
\hline 19 & Acer platanoides & 41 & 10.7 \\
\hline 20 & Acer campestre & 1 & 0.3 \\
\hline 21 & Acer negundo & 22 & 5.8 \\
\hline 22 & Tilia cordata & 55 & 14.4 \\
\hline 23 & Populus nigra & 6 & 1.6 \\
\hline 24 & Robinia pseudoacacia & 14 & 3.7 \\
\hline 25 & Prúnus doméstica & 4 & 1.0 \\
\hline 26 & Pinus sylvestris & 4 & 1.0 \\
\hline 27 & Thuja occidentalis & 18 & 4.7 \\
\hline 28 & Prunus padus & 1 & 0.3 \\
\hline 29 & Prunus avium & 5 & 1.3 \\
\hline 30 & Malus domestica & 14 & 3.7 \\
\hline 31 & Fraxinus excelsior & 16 & 4.2 \\
\hline 32 & Picea abies & 16 & 4.2 \\
\hline 33 & Picea pungens & 1 & 0.3 \\
\hline 34 & The protrusion of the building column & 1 & 0.3 \\
\hline \multirow[t]{2}{*}{35} & Advertising construction of Privatbank on the wall & 1 & 0.3 \\
\hline & & 382 & 100.0 \\
\hline
\end{tabular}

ISSN 1996-4536 (print) • ISSN 2311-0783 (on-line) • Біологічні Студії / Studia Biologica • 2021 • Том 15 / № 2 • C. 73-80 
The nests were found on a total of 30 species of trees and bushes in different settlements. In addition, in the city of Khmelnytskyi we noted 2 cases of location of woodpigeons' nests on the structural elements of buildings; similar tendencies can be observed in synanthropic populations of some European cities [2] and Western Ukraine [11]. Differences in the size of nests and eggs in pairs nested in natural biotopes and pairs nested in settlements were not revealed.

However, in the process of synanthropization, the Woodpigeon has developed new adaptations in nesting and search for food:

- building of nests in settlements begins 2 weeks earlier than in natural habitats;

- birds use the same tree for nesting for several years in a row, and often the same place in the crown of the tree (the longest term, from registered cases, -6 years);

- they use not only their own old nests, but also old nests of other species (Greenfinch (Chloris chloris), Eurasian jay (Garrulus glandarius)) as a basis for new nests;

- the minimum distance of intimidation of birds that feed on sidewalks, streets, roadsides in villages is 2 meters, and in the cities of the region $-1 \mathrm{~m}$;

- sometimes, the bird that incubates the laying does not leave the nest even when a human is at an arm's length;

- nests are often located near sidewalks at an insignificant height;

- in some parks, ring doves show elements of semi-colonial nesting when the distance between several neighboring nests varies between 5 and $10 \mathrm{~m}$;

- on average, nests in settlements are located at a height of $5.5 \mathrm{~m}$, while in forests at $10 \mathrm{~m}$;

- the latest nests with chicks in settlements were discovered in September, whereas in natural habitats - in July.

\section{CONCLUSION}

The process of synanthropization of the Woodpigeon in Upper Pobuzhia region in Ukraine has been taking place for the last 30 years. During this time, the species has inhabited all settlements in the region. Today, apparently, the density of the nesting population has reached its maximum in the settlements of the region since most of the locations suitable for nesting are occupied by nesting pairs. In its foraging behavior and tolerance to humans, the Woodpigeon resembles a typical synanthropus - Feral Pigeon Columba livia, which indicates a successful synanthropization of this species.

\section{ACKNOWLEDGEMENT}

The author is grateful to V.O. Novak for the provided unpublished materials on nesting of the Woodpigeon in the region.

\section{COMPLIANCE WITH ETHICAL STANDARDS}

Conflict of Interest: The authors declare that the research was conducted in the absence of any commercial or financial relationships that could be construed as a potential conflict of interest.

Human Rights: This article does not contain any studies with human subjects performed by any of the authors.

Animal Studies: All institutional, national and institutional guidelines for the care and use of laboratory animals were followed. 
1. Bokotei A.A. Avifauna of Lviv: population, distribution, dynamics. Lviv, 1998; 28-30. (In Russian)

2. Elvers H. Die Vogelgemeinschaft der West-Berliner Crunanlagen. Orn. Ber. Berlin (West), 1978; 3(1): 35-58.

Google Scholar

3. Hagemeijer W.J.M., Blair M.J. The EBCC Atlas of European Breeding Birds: Their Distribution and Abundance. London: T. \& A.D. Poyser, 1997. 903 p.

Google Scholar

4. Herkhner V.Iu. Materials for the study of birds of Podillya. Collection of works of the Zoological Museum of the USSR Academy of Sciences. 1928; 5: 151-192. (In Ukrainian) Google Scholar

5. Hulai V.I. A new ecological type of common wood pigeon in Podillya. Materials of the 1st conference of young ornithologists of Ukraine. Chernivtsi, 1994: 53-54. (In Ukrainian)

6. Huzii A.l. Methods for counting birds in forests. Accounting of birds: approaches, methods, results: materials of school on unification of methods of the account of birds in reserves of Ukraine, Ivano-Frankove, 26-28 April 1995. Lviv; Kyiv, 1997; 18-48. (In Russian)

7. Khorniak M. Sinurbanization of common wood pigeon (Columba palumbus L.) in Lviv. Bulletin of Lviv University. Biological series, 2003; 34: 173-179. (In Ukrainian)

Google Scholar

8. Khranevych V.P. Materials of avifauna of the western districts of Ukraine. Notes of Kamyanets-Podilsk scientific department. Poltava, 1929; 1: 5-43. (In Ukrainian)

9. Korniienko T.M., Fedun O.M. The current state of birds of the Columbiformes in Chernihiv region. Scientific Bulletin of Uzhhorod University. Biology series, 2008; 23: 59-61. (In Ukrainian) Google Scholar

10. Kuzyo G. Structure of breeding bird communities in urban and sub-urban green areas of Lviv city with different degree of anthropogenic pressure. Biol. Stud., 2016; 10(3-4): 155-164. Crossref $\bullet$ Google Scholar

11. Kuzyo H.O., Shydlovskyy I.V. Unusual breeding of Woodpigeon Columba palumbus in the western part of Ukraine. Proceedings of the Western Ukrainian Ornithological Society "Troglodytes". 2017; 8: 73-75. (In Ukrainian)

12. Loparov S.O. Avifauna of settlements of the Center of Ukraine and its changes. Kyiv, 1997. 23 p. (In Ukrainian)

13. Matviichuk O.A., Serebriakov V.V. Avifauna of the Upper and Middle Pobuzhia. Kyiv, 2010. 284 p. (In Ukrainian)

Google Scholar

14. Matviichuk O.A., Pirkhal A.B., Viduetskyi A.B. Birds of Vinnytsia region. Vinnytsia, 2017. 328 p. (In Ukrainian)

Google Scholar

15. Novak V.O. Preliminary analysis of the avifauna of the projected Upper Pobuzhia National Nature Park. Podolsky Natural Bulletin, 2010; 1: 132-152. (In Ukrainian)

Google Scholar

16. Novak V.V. General characteristics of fauna and bird population of rural settlements of Podilske Pobuzhia. Berkut, 2015; 24(2): 93-106. (In Ukrainian)

Google Scholar

17. Portenko L.A. Essay bird fauna Podolia province. Bulletin of the Moscow society of nature testers, section biology, 1928; 37(1-2): 92-204. (In Russian)

Google Scholar

18. Prychepa M.V. Current condition of the ornithofauna of the Alexandria Dendrological Park. The Journal of V.N. Karazin Kharkiv National University. Series “Biology”, 2019; 33: 55-62. (In Ukrainian)

Google Scholar

ISSN 1996-4536 (print) • ISSN 2311-0783 (on-line) • Біологічні Студії / Studia Biologica • 2021 • Том 15 / № 2 • С. 73-80 
19. Ravkin E.S., Chelintsev N.G. Methodical recommendations for integrated route counting of birds. Moscow, 1990. 33 p. (In Russian)

Google Scholar

20. Shupova T.V. Confirmation of the urban population of common wood pigeon (Columba palumbus L.) in Kyiv. Bulletin of Taras Shevchenko National University of Kyiv. Series: Problems of Physiological Functions Regulation, 2014; 17(1): 36-39. (In Ukrainian) Google Scholar

21. Shupova T.V., Koniakin S.N. Formation of nesting bird communities in parks on the gradient of anthropic load in Kiev metropolis. "Branta": Transactions of the Azov-Black Sea Ornithological Station, 2020; 23: 41-59.

Crossref $\bullet$ Google Scholar

22. Skilskyi I.V., Buchko V.V., Hodovanets B.I. About formation of a new ecological type of wood pigeon in Northern Bukovina. Berkut, 1997; 6(1-2): 49-51. (In Russian) Google Scholar

23. Tomiałojć L. The urban population of the wood pigeon Columba palumbus Linnaeus, 1758 in Europe - its origin, increase and distribution. Acta Zoologica Cracoviensia, 1976; 21: 586-631.

Google Scholar

24. Yanenko V.O., Loparov S.O. The dynamics of the population of birds in the family Columbidae of the Middle Prydniprovia region for the last ten years. Troglodytes, 2012. 98-106. (In Ukrainian)

\section{СИНАНТРОПІЗАЦІЯ ПРИПУТНЯ COLUMBA PALUMBUS У РЕГІОНІ ВЕРХНЬОГО ПОБУЖЖЯ (УКРАЇНА)}

В. В. Новак

Барський гуманітарно-педагогічний коледж ім. М. Грушевського майдан Грушевського, 1, Бар, Вінницька обл. 23000, Україна e-mail:novakvova@ukr.net

Вступ. Значна (понад 20 \%) лісистість регіону Верхнє Побужжя, широка мережа лісосмуг, високий ступінь озеленення сіл і понад 200-літні традиції садівництва створюють сприятливі умови для існування припутня (Columba palumbus) та заселення ним населених пунктів. Незважаючи на досить значне поширення виду в регіоні, його біологічні особливості і процес синантропізації залишаються недостатньо вивченими.

Матеріали і методи. Дослідження проводили протягом 2006-2020 років. Для оцінки щільності виду проводили маршрутні обліки без обмеження смуги обліку та точкові обліки. По кожному факту гніздування фріксували місце і висоту розташування гнізда, його розміри, наявність кладки чи пташенят, вік пташенят, будівельний матеріал. Основну частину матеріалу по сільських населених пунктах зібрано на території моніторингових ділянок “Чорний Острів" і “Меджибіж”, які охоплювали по 6 сіл. Також опрацьовано неопубліковані матеріали стосовно виду в регіоні В. О. Новака, які були ним зібрані у період 1990-2010 рр.

Результати. Припутень $є$ гніздовим і перелітним видом у регіоні Верхнього Побужжя. Останні десятиліття у регіоні спостерігається процес синантропізації виду. Перші випадки гніздування припутня у населених пунктах Верхнього Побужжя (західніше м. Хмельницький) виявив В. І. Гулай у 1986-1990 роках. У регіоні припутні спочатку з'явились на гніздуванні в селах (з 1986 р.) і лише

ISSN 1996-4536 (print) • ISSN 2311-0783 (on-line) • Біологічні Студії / Studia Biologica • 2021 • Том 15 / № 2 • С. 73-80 
пізніше у м. Хмельницький (перше гніздо знайдено 11.05.1994р.). Із зареєстрованих 390 гнізд частка виявлених у населених пунктах Верхнього Побужжя становила у період 1990-2000 років - 50 \%, у період 2001-2010 рр. - 64 \%, у період 2010-2020 рр. - 81 \%. У парках м. Хмельницький щільність припутня на гніздуванні на 2020 рік становить 35 пар/км², в той час як у лісових масивах регіону 4 пари/км². На деяких вулицях м. Хмельницький щільність виду на гніздуванні ще вища і становить 43 пари/км². У сільських населених пунктах щільність припутня у гніздовий період у середньому становить 1,7 пари/км ${ }^{2}$, хоча в деяких селах може сягати 11 пар/км². Птахи як опору для гнізда використовують 33 види дерев і чагарників та деякі конструктивні елементи будинків. У процесі синантропізації у припутнів з'явилися нові адаптації у гніздовій і кормопошуковій поведінці.

Висновки. Протягом останніх 30 років відбувається процес синантропізації припутня у регіоні Верхнього Побужжя. За цей час вид заселив усі населені пункти регіону. У кормопошуковій поведінці й терпимості до присутності людини нагадує типового синантропа - голуба сизого Columba livia, що свідчить про успішну синантропізацію цього виду.

Ключові слова: припутень, гніздування, синантропізація, Верхнє Побужжя 